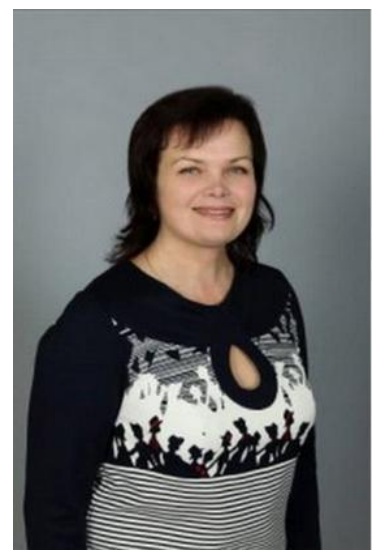

\section{Надія Дудник,}

кандидат педагогічних наук, доцент кафедри

загальної педагогіки та дошкільної освіти

Дрогобицького державного педагогічного

університету імені Івана Франка (м. Дрогобич,

Україна)

\author{
Nadiia Dudnyk, \\ $\mathrm{PhD}$ in Education, Associate Professor, Department of \\ General pedagogy and preschool education of the DSPU \\ named after Ivan Franko \\ (Drohobych, Ukraine) \\ ORCID ID 0000-0002-7879-8206
}

\title{
ВИХОВАННЯ САМОСТІЙНОСТІ У ДІТЕЙ ДОШКІЛЬНОГО ВІКУ
}

Анотація. У статті розглянуто проблему виховання самостійності у дітей дошкільного віку як одного з основних освітніх завдань. Автор аналізує проблему з позиції досліджень психологічної та педагогічної науки, окреслює питання, які ставляться в процесі розвитку дитини дошкільного віку. Під час написання статті використовувався парадигмальний метод для розкриття освітнього потенціалу виховних засад розвитку самостійності як риси характеру особистості 3 позиції педагогічної науки; синергетичний метод для аргументації педагогічних ідей педагогів засобами нелінійних зв'язків між теоріями та концепціями сучасного виховання.

Автор виокремлює необхідність вироблення стратегії сучасної освіти, яка повинна створювати спеціальне розвивальне середовище, методичні умови для фрормування самостійності у дітей в дошкільному віці у процесі розвитку. Як психологічна передумова визначена емоційна складова, яка сприяє проявам суспільно корисних справ дошкільника, дає можливість дитині опанувати самостійно цілеспрямовану діяльність, розвивати комунікативні вміння у взаємодії з ровесниками. Визначено роль педагогів у створенні спеціально організованого розвивального середовища для прояву ініціативності у дітей у грі, вільній діяльності, на дидактичних заняттях. Обґрунтовано передумови формування самостійності дошкільників.

Ключові слова: самостійність, виховання, старший дошкільник, ініціативність, самосвідомість, самоорганізація.

\section{THE BREEDING OF INDEPENDENCE BY CHILDREN OF PRIMARY AGE}

Abstract. The purpose of the article is to isolate the problem of formation of independence as an educational task in the process of upbringing of a harmoniously developed personality, which is formed at the preschool age and is decisive in the process of formation of a harmonious personality, capable of evaluating one's own abilities, striving for self-development and self-realization. The article deals with the problem of formation of independence of preschool children as an educational task.

During the writing of the article, a paradigm method was used to reveal the educational potential of the educational foundations of the development of independence as a personality trait from the standpoint of pedagogical science; Synergetic method for argumentation of pedagogical ideas of teachers by means of nonlinear connections between theories and concepts of modern education.

The author analyzes the problem of research in psychological and pedagogical science, outlines issues that are posed in the development of a child of preschool age. The author stresses the need to develop a strategy for modern education, which should create a special development environment, methodological conditions for the formation of independence by children of preschool age in the process of a child's development. As a psychological precondition, the emotional component that contributes to the manifestations of the socially useful affairs of a preschool child enables it to master self-directed activities, develop communicative skills in co-operation with coevals.

The role of teachers in the creation of a specially organized developmental environment and the initiative of children in the game, free activities, in didactic classes are defined as a prerequisite for the formation of the independence of preschoolers.

The purpose of the article is to isolate the problem of formation of independence as an educational task in the process of upbringing of a harmoniously developed personality, which is formed at the preschool age and is decisive in the process of formation of a harmonious personality, capable of evaluating one's own abilities, striving for self-development and self-realization.

Keywords: independence, education, upbringing, senior preschooler, initiative, self-awareness, self-organization.

ВСТУП

Постановка проблеми. Функціонування сучасної системи дошкільної освіти ґрунтується на основних положеннях Конвенції ООН про права дитини (1989), Законах України «Про охорону дитинства» (2001), «Про 
освіту» (2017), «Про дошкільну освіту» (2018), інших чинних нормативно-правових актах. Зміст освітньої роботи з дітьми дошкільного віку має відповідати основним вимогам та концептуальним засадам Базового компонента дошкільної освіти України (2012): «Оволодіння змістом дошкільної освіти впродовж всього періоду дошкільного дитинства, визнання цінності кожної вікової сходинки в особистісному розвитку при повній реалізації дитиною своїх потенційних можливостей» [1, с. 4].

Розглядаючи дошкільний вік як період формування особистісних якостей, концепція сучасної української освіти визначає сутність нового підходу до дошкільного виховання, заснованого на принципах варіативного змісту, педагогіки розвитку, активного пізнання світу через види суспільної діяльності, виховання дитини як самостійного та ініціативного творця майбутнього. Вченими розроблено механізм, що регулює якість дошкільного виховання, зокрема, державний стандарт визначає критерії оцінки діяльності закладів дошкільної освіти, її концептуальні засади, де звертається увага на фрормування особистісних якостей дитини - допитливості, ініціативності, комунікабельності, творчості, самостійності. Проте, окремо завдання виховання самостійності як необхідної характеристики людини нового часу в концепції не висувається. Хоча моральні та особистісні якості характеру дитини виховуються саме через самостійність, яка активно проявляється у вихованців саме у старшому дошкільному віці (усвідомлення мети діяльності і наполегливість у її досягненні; готовність доводити розпочату справу до кінця; прояв емоційнопозитивного ставлення у вияві ініціативи; вміння критично оцінювати результати діяльності; прагнення доводити розпочату справу до логічного завершення, співпрацювати в колективі, визнавати успіхи інших, а також дбайливе ставлення до праці) [1, с. 5]. Вважаємо за необхідність виокремити завдання ЗДО у виробленні самостійності дошкільників як запоруки подальшого творчого, свідомого, відповідального ставлення дитини до власного буття та розвитку.

МЕТА І ЗАВДАННЯ ДОСЛІДЖЕННЯ.

Підкреслити необхідність виокремлення завдань у самостійності як якості особистості, що починає фрормуватися в дошкільному віці і $€$ визначальною в процесі становлення гармонійної особистості, яка здатна оцінювати власні можливості, прагнути до саморозвитку та самореалізації. Завданнями ставимо сформулювати вимоги до педагогів та батьків у сприянні формування навичок самостійності дитини старшого дошкільного віку.

\section{МЕТОДИ ДОСЛІДЖЕННЯ.}

Під час написання статті використовувався парадигмальний метод для розкриття освітнього потенціалу виховних засад розвитку самостійності як риси характеру особистості з позиції педагогічної науки; синергетичний для аргументації педагогічних ідей педагогів засобами нелінійних зв'язків між теоріями та концепціями сучасного виховання.

\section{РЕЗУЛЬТАТИ ДОСЛІДЖЕННЯ}

Дошкільний вік як основа соціалізації розвитку дитини є найбільш відповідальним етапом дитинства. Висока сенситивність цього вікового періоду визначає великі потенційні можливості різнобічного розвитку дитини.

Самостійна діяльність - одна з передумов якісної організації освітнього процесу дітей дошкільного віку. Відповідно до концепції Л. Виготського вона починає формуватися у спільній моделюючій діяльності зі значущим дорослим (ранній дошкільний вік), згодом у взаємодії з ровесниками (молодший дошкільний вік) стає самостійною цілеспрямованою, організованою працею дитини (середній та старший дошкільний вік) [2, с. 413].

Самостійність - це багатоаспектний психологічний феномен діяльності особистості, що має власні конкретні критерії. «Це вольова властивість особистості як здатність систематизувати, планувати, регулювати і активно здійснювати свою діяльність без постійного керівництва і практичної допомоги ззовні [8, с. 312].

Самостійність як характеристика діяльності дошкільника проявляється у здатності досягати мети діяльності без сторонньої допомоги. Самодіяльність - суб'єктивна, індивідуальна активність з особистісно зумовленими компонентами: метою, провідною потребою, мотивацією і способами реалізації. Самоактивація - це суб’єктивно зумовлена внутрішня мотивація діяльності. Самоорганізація - властивість особистості мобілізувати себе, цілеспрямовано, активно використовувати всі свої можливості для досягнення проміжних і кінцевих цілей, раціонально використовуючи при цьому час, сили. Саморегуляція - спочатку психологічне забезпечення діяльності, у подальшому розвитку набуває особистісного сенсу, тобто власного смислового або емоційного наповнення. Самоконтроль - узагальнююча діяльність, яка здійснюється з метою осягнення результату на особистісному рівні.

Проявляється самостійність у дошкільному віці через самосвідомість, що визначається «діяльністю і здібностями особистості, які пов'язані з умінням організувати себе. Проявляється в цілеспрямованості, активності, обґрунтованій мотивації, плануванні своєї діяльності, самостійності, швидкості прийняття рішень і відповідальності за них, критичності оцінки результатів своїх дій, почутті обов'язку» [8, с. 311].

Ініціатива - частий прояв дитини як індивіда - вказує на наявність у суб'єкта здатності до самостійної дії, що змінює ії власний стан, всупереч природній інерції. Це також внутрішнє спонукання до нових форм діяльності, підприємливості, втілення в життєдіяльність ідей.

Самостійна діяльність в спеціальному педагогічному середовищі - це така робота, яка виконується без безпосередньої участі вихователя, але за його завданням у спеціально відведений для цього час, при цьому дитина свідомо прагне досягти поставленої мети, використовуючи свої зусилля і виражаючи в тій чи іншій формі результат розумових, фізичних, соціальних дій. 
Самостійна діяльність як усвідомлена поведінка дитини найбільш повно визначається О. Кононко: «Становлення довільної вольової поведінки - важливий складник особистісного зростання дошкільника. Дитина за сформованими навичками вольової поведінки (старший дошкільний вік) здатна самостійно зробити вибір, надати перевагу, відмовити у прихильності, протистояти тиску інших» [5, с. 3], що створює передумови для вироблення власних моральних цінностей, свідомого використання знань про світ, умінь та навичок, вироблення соціальної поведінки на засадах самостійності, яка сприяє становленню високого рівня самосвідомості, рефолективності, самодисципліни, особистої відповідальності і приносить дитині задоволення як процес самовдосконалення та самопізнання.

Самостійна діяльність дошкільника $€$ наслідком правильно організованої пізнавальної діяльності в процесі виховання, що мотивує самостійне її розширення, поглиблення і продовження у вільний час. Для вихователя це означає чітке усвідомлення власного плану дій, усвідомлене його формування у дошкільників як певної схеми освоєння нового предмета, явища або дії в ході вирішення нових завдань.

Ефективність виховного процесу і пізнання визначається якістю викладання та самостійної пізнавальної діяльністю. Ці два поняття дуже тісно пов'язані, але слід виділити самостійну роботу як провідну і активізуючу форму виховання тому, що:

1) знання, навички, вміння, звички, переконання, духовність не можна передавати від вихователя до дитини так, як передаються матеріальні предмети. Кожна дитина опановує їх шляхом самостійного пізнавального процесу: спостереження, прослуховування, усвідомленням усної інформації, аналіз, переосмислення;

2) процес пізнання, спрямований на виявлення сутності та змісту досліджуваного явища, підпорядковується психологічним законам, визначається послідовністю пізнання: знайомство, сприйняття, переробка, усвідомлення, сприймання. Порушення послідовності призводить до поверхневих, неточних, неаргументованих знань, які практично не можуть реалізуватися;

3) дитина в процесі самостійної діяльності живе в стані найвищого інтелектуального напруження, що дає можливість розвиватися; дитина фрормується як особистість і представник культури.

Самостійна робота дитини виробляє високу культуру розумової праці, яка передбачає не тільки володіння технікою розумових операцій, але й потребу в самостійній діяльності, прагнення вникнути в суть питання, ще не вирішених проблем. У процесі такої праці найбільш повно виявляються індивідуальні здібності дошкільнят, їх нахили та інтереси, які сприяють розвитку вміння аналізувати факти та явища, вчать самостійного мислення, яке призводить до творчого розвитку та формування власної думки, своїх поглядів, уявлень, своєї позиції [3, с. 64]

Т. Поніманська зазначає: «Майстерність вихователя полягає в тому, щоб підвести дітей до самостійних «відкриттів», стимулювати їхню пізнавальну діяльність» $[7$, с. 376]. Педагоги С. Козлова, Т. Куликова звертають увагу в дослідженнях на те, що трудова діяльність дошкільників є засобом дослідження світу та осмисленням себе у продуктивній діяльності: «У процесі праці діти набувають трудових навичок і вмінь, що допомагають дитині ставати незалежною від дорослого і самостійною» [6, с. 123].

Проблема самостійної роботи завжди приковувала до себе увагу вчених і педагогів-практиків. I це закономірно: одна з умов ефективності виховання - прищеплення дітям навичок самостійної роботи над різним матеріалом, що пояснюється тими цілями і завданнями, які стоять нині перед дошкільними установами: підготувати особистість до життя, до активної участі у праці, творчого розвитку.

До основних проявів розвитку самостійності дошкільників Л. Фесюкова відносить:

- здатність визначати підставу для тих чи інших учинків, вибір поведінки;

- здатність відокремлювати власну позицію;

- здатність до незалежної реалізації структурних блоків пізнавальної діяльності;

- планування, регулювання і аналіз своєї діяльності без допомоги інших;

- вміння співвідносити свої прагнення і можливості, адекватно оцінювати процес своєї діяльності [10, с. 30]. Автори програми «Дитина» під самостійністю розуміють своєрідну форму активності, яка відображає рівень розвитку дитини, забезпечує ініціативу в постановці завдань, бажання розв'язати проблему, яка виникає в житті та діяльності [3, с. 63] У дослідженнях сучасних науковців теоретично обґрунтовується проблема формування самостійності особистості в світлі виховання основних якостей представника сучасної епохи - ініціативності, самостійності, творчої активності - як головних показників всебічного розвитку людини.

Самостійність розвивається поступово, і починається цей процес у гармонії з проявами психологічними, емоційними, комунікативними, пізнавальними. Шестирічна дитина сприймає світ не за окремими елементами, а цілісно, з'являється цілеспрямованість. Спостережливість, уміння виокремити та узагальнити сприяють розвитку мислення. У старшого дошкільника активізується довільна та мимовільна увага, мислення набуває наочно-образної форми. Операції з предметами мають оцінно-дієвий характер (класифікація, узагальнення, виокремлення, поєднання). У старшого дошкільника починає розвиватися словесно-логічне мислення. Пам'ять вихованця шостого року життя перебуває у стані переходу від мимовільної до свідомої.

Активно вдосконалюється словниковий запас, мовлення набуває ознак розмірковування, що сприяє розвитку здатності діяти подумки. Розповідь стає зв'язною, вживаються складні речення, проявляються творчі задатки. 
Також мовлення розвивається у спілкуванні з однолітками (постановка запитань, розповідь, розмірковування, франтазія, детальна характеристика предметів, явищ, використання жартів).

Пізнавальна активність продовжує зростати, а численні запитання стають поширеними, потребують детальнішого пояснення, спрямовуються на пізнання навколишнього світу для отримання теоретичних знань і подальшого їх використання.

Під впливом дорослого поступово виникає якісно нова фрорма спілкування - особистісна. Дитина потребує уваги, поваги до власної думки, прагне відчувати взаєморозуміння, співчуття. Діти стають більш стриманими, засвоюють «мову почуттів»: міміку, жести, пози, інтонації голосу тощо. Упродовж старшого дошкільного віку дитина набуває здатності довільно керувати пізнавальними процессами, планувати діяльність, співпрацювати в групі, оцінювати результати діяльності.

Ігри старших дошкільнят стають різноманітними та розгорнутими, їм властиве ускладнення сюжету, вони набувають більш творчого характеру, з дидактичних, індивідуальних перетворюються на сюжетно-рольові, моделюючі та групові.

Здатність до самоконтролю - завершальний етап формування самостійності в предметній діяльності. Оволодівши здатністю самостійно планувати, здійснювати та контролювати ії, малюк стає вже певною мірою незалежним від дорослого. Але це лише перший і дуже скромний крок на шляху до зрілої самостійності. Самостійні навички старших дошкільників стосуються лише вузько окреслених операцій, які були схвалені дорослими, дістали визнання, підкріпилися позитивними емоціями. Вони не проектуються на наступний досвід у навчально-пізнавальній діяльності, а є корисними тільки з точки зору фрормування комунікативного досвіду. Дорослий підкріплює похвалою бажання дитини ставати самостійним відкривачем та дослідником навколишнього світу.

Р. Павелків визначає самостійність як прояв основ формування характеру, вміння діяти за власною ініціативою, помічати необхідність своєї участі в тих чи інших обставинах; вміння виконувати звичні справи без звернення за допомогою і контролю дорослого; вміння усвідомлено діяти в ситуації заданих вимог та умов діяльності; вміння усвідомлено діяти в нових умовах (визначити мету, врахувати умови, здійснювати елементарне планування, отримати результат); вміння здійснювати елементарний самоконтроль і самооцінку результатів діяльності; вміння переносити відомі способи дій в нові умови [6, с. 245]. Адже самостійність - це здатність особистості планувати, здійснювати контроль над своєю діяльністю на основі наявних знань, умінь та навичок, і дитина отримує велике задоволення, якщо самостійно робить власні висновки, проявляє бажання розмірковувати. Якщо це міркування виявляється правильним, підтриманим дорослим, то такий процес приносить моральне задоволення, підкріплюється і стає моделлю поведінки.

Відокремлення себе від інших людей, усвідомлення власних можливостей через почуття володіння тілом, відчуття себе джерелом волі призводять до появи нового типу взаємин між дитиною та дорослим. Вона починає себе порівнювати з дорослим і хоче користуватися тими ж правами, що і дорослі: виконувати такі ж дії, бути такою ж незалежною і самостійною. Бажання бути самостійною виражається не тільки в пропонованих дорослим формах, а й у наполегливому прагненні вчинити так, а не інакше. Дитина відчуває себе джерелом своєї волі, а це важливий момент у розвитку самоусвідомлення.

Різке зростання самостійності іноді стає причиною нерозуміння з боку дорослого, виникає конфлікт. На жаль, дорослий не завжди враховує потребу дитини звільнитися від опіки і протестує проти проявів активності дитини, сприймаючи це як свавілля, прогнозуючи можливу небезпеку, бажання контролювати дії дитини. Тому основною і необхідною умовою для формування самостійності $є$ правильна організація атмосфери взаємин між дорослим та дитиною, виключно важлива атмосфера довіри, дружелюбності, витримки з боку дорослих.

Прагнення до самостійності виникає і розвивається від рівня оволодіння дитиною навичками та вмінням у самообслуговуванні, тобто навчання умінь $є$ вирішальним при формуванні самостійності. Також важливу роль відіграє створення сприятливої, заохочувальної атмосфери при виникненні бажання дитини до самодіяльності.

Великого значення самостійній діяльності дитини у вихованні надавала відомий педагог М. Монтессорі. Вона зазначала, що дитина у три роки - це вже людина, і провідне завдання дорослих полягає у створенні спеціального розвивального середовища, через вивчення якого дитина пізнає світ і таким чином його для себе відкриває. М. Монтессорі підкреслювала, що освіта - це не те, що робить педагог, а природний процес, який розвивається спонтанно в людській істоті. Освіта набувається не завдяки слуханню слова, а через особистий досвід, який дитина розвиває в середовищі, що ії оточує. Завдання педагога не говорити, а підготувати серію предметів-стимулів для культурної діяльності в спеціальній обстановці, влаштованій для дитини. Адже для розвитку дитини як особистості та як самостійної людини їй у дошкільному віці необхідно створити розвивальне середовище, в якому вона «могла б розвиватися в індивідуальному темпі і найповніше розкрити свій внутрішній потенціал у процесі вільної самостійної діяльності » [9, с. 136]

Завдання педагогів та батьків - демонструвати свою побутову чи суспільну працю, зважаючи на те, що дитина мимоволі спостерігає, завжди пам'ятати, що праця дорослих виховує ставлення до неї маленьких членів сім'ї,

а педагог в ЗДО повинен 3 виховною метою привертати увагу дітей до своєї суспільно-корисної праці, вголос проговорювати її необхідність, виконувати з добрим настроєм, заохочуючи по можливості дітей до спільної участі. 


\section{ВИСНОВКИ ТА ПЕРСПЕКТИВИ ПОДАЛЬШИХ ДОСЛІДЖЕНЬ}

Самостійна діяльність - це вища форма пізнавальної діяльності дошкільника, що є проявом активності в пізнанні світу та пошуку себе у ньому як дієвого будівничого. Тому завданням цілісного педагогічного процесу є сприяння ініціативності дитини, задоволення пізнавальних інтересів, формування вмінь комунікації та взаємодії з дорослими й однолітками з метою виховання дієвої, емоційно стабільної особистості.

Аналіз праць, присвячених проблемі самостійної діяльності дошкільників (О. Кононко, Р. Павелків, Т. Поніманська, М. Чепіль) показав, що поняття самостійної діяльності трактується як необхідність спеціальної організаційної та методичної роботи для вироблення даної якості дитиною.

Проблема активізації самостійності дошкільників в процесі виховної роботи - одна із актуальних проблем і педагогічної науки, і практики. У педагогіці самостійна діяльність - це одна з вольових сфер особистості, вміння не піддаватися впливу різних фракторів, діяти на основі своїх поглядів і спонукань. Самостійність - незалежність, свобода від зовнішніх впливів, примусів, від сторонньої підтримки, допомоги.

Щоб успішно формувати самостійність у процесі розвитку дитини, потрібно підтримувати прояви суспільно корисних справ дошкільника, давати можливість дитині опанувати самостійно цілеспрямовану діяльність, розвивати комунікативні вміння взаємодії з ровесниками. Без досвіду самостійної діяльності в подальшому процесі самовдосконалення в дитини можуть виникнути проблеми невпевненості, пасивності, байдужості. Основи самостійності формуються в дошкільному віці через педагогічно доцільно організоване розвивальне середовище, засобами педагогіки є сприяння дитячій ініціативності, надання можливостей практичного використання власного досвіду, участі в суспільно корисній діяльності, розумовому розвитку, у творчих справах тощо. Виховання самостійності $€$ важливим у формуванні позитивних рис характеру (відповідальність, акуратність, обов'язковість, цілеспрямованість, вміння доводити розпочату справу до завершення, бути корисним людям тощо), налагодження комунікативних умінь (спілкування, самопрезентація, вміння висловлювати власну думку, проявляти творчість тощо), вироблення активної соціальної позиції як індивіда (мати власні переконання, бути соціально ініціативним, виробляти стійку громадянську позицію тощо).

\section{СПИСОК ВИКОРИСТАНИХ ДЖЕРЕЛ}

[1] Базовий компонент дошкільної освіти / Науковий керівник:А. М. Богуш, дійсний член НАПН України, проф, д-р пед. наук. Київ: Видавництво, 2012.26 с.

[2] Выготский Л. Психология развития ребенка. Москва: Смысл; Эксмо, 2004. 512 с.

[3] Дитина: Програма виховання і навчання дітей від 3 до 7 років./ Е. В. Бєлкіна, Н. М. Бібік, М. С. Вашуленко. К.: Богдан, 2003. 327 c.

[4] Зимова О. Що таке самостійна дитина / Дошкільне виховання. 2008 . № 11. С.60 - 64.

[5] Кононко О. Запорука особистісного зростання дошкільника / Дошкільне виховання. № 10, 1999. С. 3 - 4.

[6] Павелків Р. Дитяча психологія: навч. посіб. для самостійної роботи студента / Р. В. Павелків, О. П. Цигипало. Київ: Академвидав, 2011. 376 с.

[7] Поніманська Т. І. Дошкільна педагогіка : навчальний посібник для студентів вищих навчальних закладів. Київ:Академвидав, 2006. $456 \mathrm{c}$.

[8] Тлумачний російсько-український словник психологічних термінів: Словник. Київ: ВД «Професіонал», 2007. 512 с.

[9] Чепіль М., Дудник Н. Педагогічні технології: навч.-метод. пос. Київ: Академвидав, 2012. 220 с.

[10] Фесюкова Л. Учусь керувати собою: комплексні заняття для дітей 3 - 5 років. Харків: ПП «ГРО ПЛЮС», 2008. 208 с.

\section{REFERENCES (TRANSLATED AND TRANSLITERATED)}

[1] Bazovyy komponent doshkilnoyi osvity (Basic component of preschool education) / Naukovyy kerivnyk:A. M. Bohush, diysnyy chlen NAPN Ukrayiny, prof, d-r ped. nauk. Kyyiv: Vydavnytstvo, 2012. 26 s. (in Ukrainian)

[2] Vyhotskyy L. Psykholohyya razvytyya rebenka (Psychology of Child Development). Moskva: Smysl; Éksmo, 2004. 512 s. (in Russian)

[3] Dytyna: Prohrama vykhovannya i navchannya ditey vid 3 do 7 rokiv (Child: A program for the upbringing and education of children from 3 to 7 years old)./ E. V. Byelkina, N. M. Bibyk, M. S. Vashulenko. K.: Bohdan, 2003. 327 s. (in Ukrainian)

[4] Zymova O. Shcho take samostiyna dytyna (What is an independent child). / Doshkilne vykhovannya. 2008 . № 11. S.60 - 64. (in Ukrainian)

[5] Kononko O. Zaporuka osobystisnoho zrostannya doshkilnyka (The key to personal growth of preschoolers) / Doshkil'ne vykhovannya. № 10, 1999. S. 3 - 4. (in Ukrainian)

[6] Pavelkiv R. Dytyacha psykholohiya: navch. posib. dlya samostiynoyi roboty studenta (Children's Psychology: Teach. manual for independent work of the student) / R.V.Pavelkiv, O.P.Tsyhypalo. Kyyiv: Akademvydav, 2011. 376 s. (in Ukrainian)

[7] Ponimanska T.I. Doshkilna pedahohika : navchalnyy posibnyk dlya studentiv vyshchykh navchalnykh zakladiv (Preschool Pedagogy: Textbook for Students of Higher Educational Institutions). Kyyiv:Akademvydav, 2006. 456 s. (in Ukrainian)

[8] Tlumachnyy rosiysko-ukrayinskyy slovnyk psykholohichnykh terminiv: Slovnyk (Explanatory Russian-Ukrainian dictionary of psychological terms: Dictionary). Kyyiv: VD «Profesional», 2007. 512 s. (in Ukrainian)

[9] Chepil M., Dudnyk N. Pedahohichni tekhnolohiyi (Pedagogical technologies): navch.-metod. pos. Kyyiv: Akademvydav, 2012. 220 s. (in Ukrainian)

[10] Fesyukova L. Uchus keruvaty soboyu: kompleksni zanyattya dlya ditey 3 - 5 rokiv (I learn to manage myself: complex classes for children from 3 to 5 years old.). Kharkiv: PP «HRO PLYUS», 2008. 208 s. (in Ukrainian) 